\title{
IMPLEMENTASI APLIKASI E-SURAT PADA PERANGKAT DESA DI DESA MENTURUS KUDU JOMBANG
}

\author{
${ }^{1}$ Hadi Sucipto, ${ }^{2}$ Ahmad Heru Mujianto, ${ }^{3}$ Chamdan Mashuri, ${ }^{4}$ Mahrus Ali, ${ }^{5}$ Mahfudiyanto \\ ${ }^{1}$ Program Studi Manajemen Informatika, ${ }^{2,3}$ Program Studi Sistem Informasi, ${ }^{4}$ Program Studi Teknik Informatika, \\ ${ }^{5}$ Program Studi Manajemen, Universitas Hasyim Asy’ari Tebuireng Jombang \\ 1tejomojoagung@gmail.com
}

\begin{abstract}
Village Services describe the identity of the Village itself. During this time the service of making letters at the Menturus Village office uses services in the form of a manual information system, the service is carried out by an officer. Some problems faced by the service system like this are difficult and slow in the process of proposing new letters, permits and certificates. While the public wants friendly, fast and effective services. E-SuratDesa service system can be used as a solution to provide excellent service to the community. This system is expected to enable the community to access services such as taking care of certificates and cover letters for various purposes by entering or typing the Personal Identification Number (NIK) into the village self-service website. If data is found, the public can immediately perform the desired service. The results of this study are web-based village administration applications.
\end{abstract}

Keywords: web, village office, E-SuratDesa

\begin{abstract}
Abstrak
Pelayanan Desa menggambarkan identitas Desa itu sendiri. Selama ini pelayanan pembuatan surat di kantor Desa Menturus menggunakan pelayanan dalam bentuk sistem informasi manual, pelayanan dilakukan oleh sorang petugas. Beberapa permasalahan yang dihadapi dari sistem pelayanan seperti ini seperti sulit dan lambat dalam proses pengajuan usulan surat baru, surat ijin dan surat keterangan. Sementara masyarakat menginginkan pelayanan yang ramah, cepat dan efektif. Sistem layanan E-SuratDesa dapat dijadikan solusi untuk memberikan layanan prima kepada masyarakat. Sistem yang dibangun ini diharapkan masyarakat dapat mengakses layanan seperti mengurus surat keterangan dan surat pengantar untuk berbagai keperluan dengan cara memsukkan atau mengetik Nomor Induk kependudukan (NIK) ke web layanan mandiri desa. Jika data ditemukan, masyarakat bisa langsung melakukan layanan yang diinginkan. Hasil dari penelitian ini adalah aplikasi administrasi desa berbasis web.
\end{abstract}

Kata Kunci : web, kantor desa, E-SuratDesa

\section{PENDAHULUAN}

Pemerintah Desa merupakan instansi Pemerintah yang berada pada tingkat yang paling bawah, dalam Permendagri No.84 tahun 2015, menyatkan bahwa Pemerintah Desa menyelenggarakan urusan Pemerintahan dan kepentingan masyarakat setempat dalam dalam sistem pemerintahan Negara Kesatuan Republik. Pemerintahan Desa melayani masyrakat di Kantor Desa menggambarkan identitas Desa itu sendiri (Kemendagri, 2016).

Desa Menturus merupakan salah satu Desa di Kecamatan Kudu, Kabupaten Jombang dengan kurang lebih sebanyak 2.516 orang terdaftar sebagai warga Desa Menturus. Di desa ini sebagian proses pelayanan tersebut masih dilakukan secara konvensional yaitu yaitu pelayanan surat menyurat dan penolahan data masih menggunakan program pengolah kata (Ms.Office), sehingga prosesnya membutuhkan waktu yang lebih lama untuk melakukan pelayanan dan dokumentasi berkas surat kurang teradministrasi dengan baik sehingga sering kali terjadi kesalahan bahkan ada arsip data yang hilang atau rusak karena terlalu banyaknya arsip yang ada. Ada beberapa hal yang dapat menimbulkan kendala pada suatu sistem yang dijalankan secara manual, diantaranya adalah banyaknya jumlah data yang harus diolah, kerumitan dalam pemrosesan suatu data, terbatasnya waktu yang 
digunakan dalam mengolah data, dan data yang beraneka ragam. Begitu pula dalam sebuah Kantor Kepala Desa dalam mengelola surat menyurat masih dikerjakan cara manual, akan terbentur pada kendala, sehingga kan mengurangi kinerja suatu instansi (Suryadi 2013).

Pemerintahan Desa juga harus memperhatikan dengan baik kinerja pelayanan administrasinya demi menciptakan sebuah sistem pelayanan yang lebih efektif, efisien dan tetap tepat sasaran. Improvisasi terhadap perkembangan dunia teknologi juga diperlukan guna memanfaatkan fungsi teknologi dengan positif.

Berdasarkan permasalahanpermasalahan tersebut, kegiatan pengabdian kepada masyarakat yang kami lakukan di Universitas Hasyim Asy'ari tahun 2019 ini bertujuan, mencoba melakukan pengembangan sistem pelayanan baru berbasis web yang berjudul "Implementasi Aplikasi E-Surat Pada Perangkat Desa" pada Studi kasus di Desa Menturus, Kecamatan Kudu, Kabupaten Jombang. Dengan adanya sistem pelayanan baru ini diharapkan dapat meningkatkan efektifitas, efisiensi, dan fleksibilitas dengan memanfaatkan kemampuan sistem ini.

\section{METODE}

Metode yang digunakan dalam melaksanaan pengabdian kepada masyarakat ini adalah dengan pendekatan secara langsung dengan Perangkat Desa Menturus Kecamatan Kudu Kabupaten Jombang, adapun tahapantahapan yang dilakukan dapat dilihat pada Gambar 1.

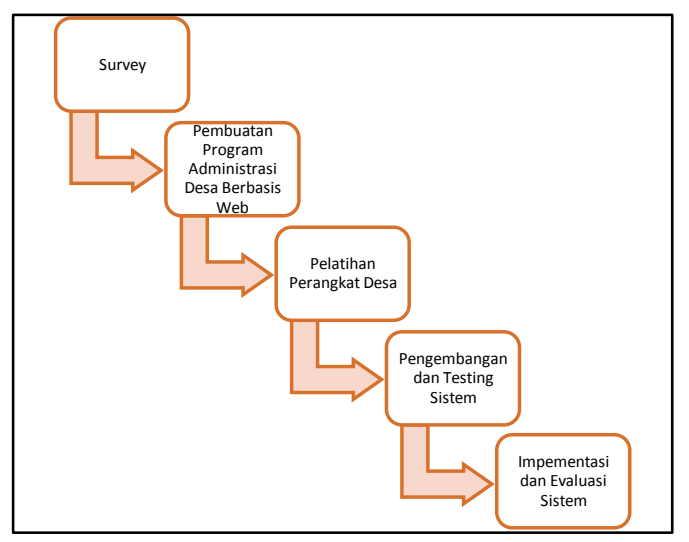

Gambar 1.Roadmap Pelaksanaan PKM

Berikut ini penjelasan untuk tiap tahapan :

Survey

Tahapan pertama adalah melaksanakan survey ke bagian admintrasi desa Menturus untuk melihat secara langsung proses pembuatan surat, mulai dari cara perangkat desa melayani pembuatan surat. Hasil dari survey berupa pengumpulan data yang akan berguna untuk menindaklanjuti proses selanjutnya.

Survey lokasi dilakukan pada hari Kamis 15 Nopember 2019, dengan langsung mendatangi Kantor Desa Menturus dengan melakukan pengamatan serta wawancara dengan perangkat desa, yang kebetulan pada saat berkunjung ke lokasi sedang ada proses pembuatan surat pengantar SKCK.

\section{Pembuatan Program Administrasi Desa}

Dalam pengabdian kepada masyarakat ini terdapat 2 bagian pokok dalam web aplikasi, yaitu client side dan server side. Dalam hal ini yang dimaksud sisi client adalah PC (Personal Computer) atau bisa juga perangkat mobile yang terhubung ke jaringan internet. Sedangkan yang dimaksud sisi server adalah Komputer Server, Hosting, atau VPS sebagai pelayan permintaan dari client. Untuk lebih jelasnya mengenai skema Web Aplikasi, maka dapat dilihat pada Gambar 2. 


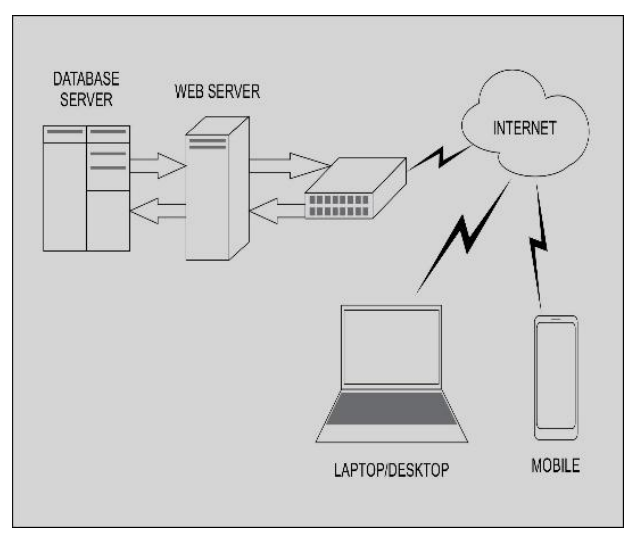

Gambar 2 Skema Web Aplikasi

Untuk jaringan Internet, aplikasi pelayanan surat administrasi desa menggunakan WIFE terpadu di Kantor Desa Menturus, sedangkan spesifikasi hardware menyesuaikan perangkat yang ada di desa menggunakan sistem operasi Microsoft Window7, spesifikasi computer Corei3, kebutuhan memori 2GG byte dan Printer untuk mencetak berbgai macam surat.

Pelayanan Surat Administrasi Desa Online berbasis Web dan mengelola aplikasi tersebut pada beberapa konten yang tersedia di aplikasi administrasi pelayanan surat (entry penduduk, surat keterangan , surat keterangan kelakuan baik, surat keterangan domisili, surat keterangan kurang mampu dan lain-lain), sehingga perangkat desa tidak hanya memakai sistem secara konvensional tetapi juga mampu merawat aplikasi sistem jika terjadi kendala.

\section{Pelatihan Perangkat Desa}

Sistem yang sudah berhasil dibuat selanjutnya akan diterapkan pada perangkat desa dengan cara memberikan pelatihan tentang penggunaan sistem. Pada pelatihan sistem ini meliputi pengenalan surat menyurat, instalasi software aplikasi, peranan teknologi informasi dalam administrasi desa, pengenalan aplikasi surat administrasi desa online dan pembuatan akun online, praktikum entry data penduduk, praktikum pelayanan pembuatan surat dan praktikum pelayanan pembuatan surat dan pembuatan laporan.

\section{Pengembangan dan Testing Sistem}

Merupakan tahapan lanjutan dari hasil desain dan perancangan yang selanjutnya dilakukan proses pengembangan atau development sistem yang dibangun sesuai dengan hasil analisa dan perancangan sistem tersebut. Development sistem dari awal hingga akhir nantinya di uji coba atau testing sistem ke desa.

\section{Implementasi dan Evaluasi Sistem}

Dari hasil pembangunan sistem dan testing sistem yang siap di implementasikan, sistem yang dibuat langsung di implementasikan ke desa Menturus yang bertujuan untuk mengetahui langsung kesesuaian dengan lapangan apakah masih ada koreksi dan evaluasi untuk perbaikan dan kesesuaian dengan lapangan atau user. Tahap selanjutnya adalah evaluasi, yaitu untuk mengetahui sejauh mana pemahaman perangkat desa terhadap materi maupun pelatihan yang sudah didapatkan. Kriteria keberhasilan dalam PKM ini adalah jika $80 \%$ peserta mampu mengetahui pentingnya pemanfaatan teknologi informasi dalam menjalankan proses bisnis. Evaluasi juga dilakukan terhadap penggunaan E-SuratDesa, dengan cara memonitoring aktivitas yang terjadi pada website tersebut, setelah dilakukan pelatihan.

\section{HASIL DAN PEMBAHASAN}

Pengabdian kepada masyarakat ini merupakan tindak lanjut dari kegiatan KKNT yang dilaksanakan pada bulan Juli-Agustus 2019. Berdasarkan hasil pengamatan dan observasi yang dilaksanakan pada saat KKNT, diketahui bahwa pada desa Menturus terdapat beberapa pelayanan adminstrasi desa yang kurang optimal, hal tersebut yang menjadikan topik pada pengabdian ini berfokus dalam pembuatan E-SuratDesa dan pengenalan teknologi informasi pada perangkat desa. 
Berikut ini hasil yang didapatkan dari hasil pelaksanaan PKM ini:

\section{Website E-SuratDesa}

Salah satu produk dari hasil pelaksanaan PKM ini berupa sistem E-uratDesa yang dipergunakan sebagai sistem pelayanan administrasi Desa. Berikut ini tampilan dan fitur-fitur yang terdapat dalam website E-Desa.

\section{1) Tampilan Halaman Utama}

Halaman ini merupakan halaman awal ketika kita membuka atau mengakses website $E$ SuratDesa. Halaman ini dapat diakses oleh siapapun selama pengguna memasukkan alamat website dengan benar dan tersambung dengan jaringan internet. Pada halaman ini terdapat beberapa fitur seperti aplikasi administrasi pelayanan surat (entry penduduk, surat keterangan, surat keterangan kelakuan baik, surat keterangan domisili, surat keterangan kurang mampu dan lain-lain), sehingga perangkat desa tidak hanya memakai sistem secara konvensional tetapi juga mampu merawat aplikasi sistem jika terjadi kendala. Berikut ini tampilan halaman utama seperti yang terlihat pada Gambar 3.

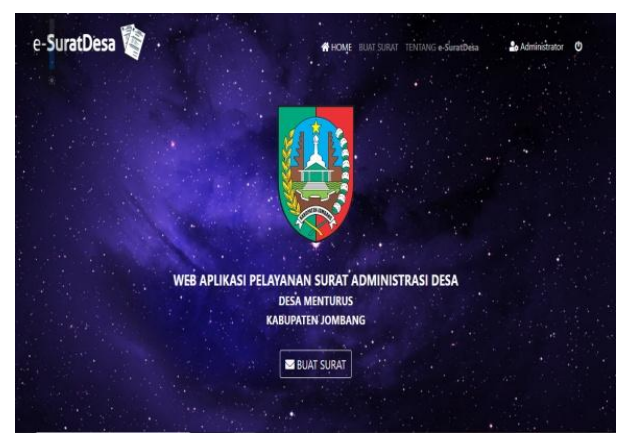

Gambar 3. Halaman Utama E-SuratDesa

\section{2) Tampilan Halaman Validasi NIK}

Halaman ini merupakan validasi NIK sebelum proses lain dijalankan. Berikut ini tampilannya seperti yang terlihat pada Gambar 4.

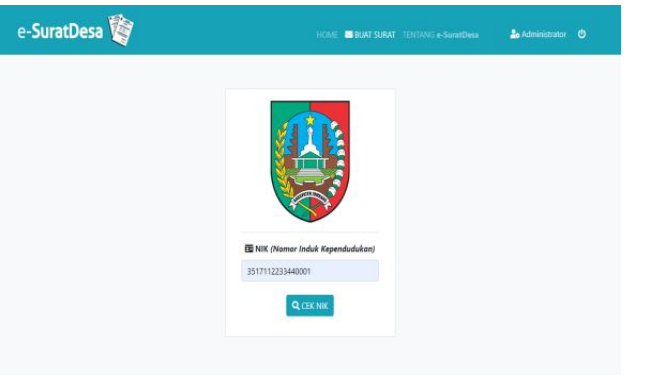

Gambar 4. Halaman Validasi NIK

\section{3) Tampilan Jenis Surat}

Halaman ini merupakan Aplikasi pelayanan secara online dengan memanfaatkan konten pengelolaan data jenis surat. Berikut tampilannya seperti yang terlihat pada Gambar 5.

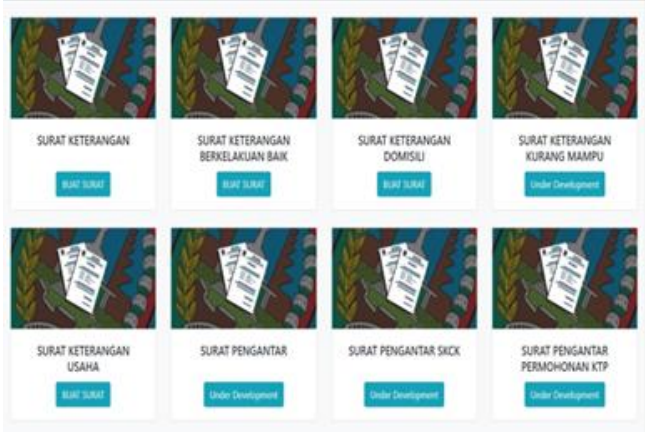

Gambar 5. Halaman Jenis Surat

\section{4) Tampilan Halaman Dashboard Aplikasi}

Halaman ini merupakan tampilan setelah user berhasil login. Pada menu utama ini akan terdapat beberapa menu diantaranya untuk kelola admin (form input data surat masuk/keluar, form input data klasifikasi, form arsip foto, form pengaturan user).Berikut ini tampilan halaman dashboard aplikasi seperti yang terlihat pada Gambar 6. 


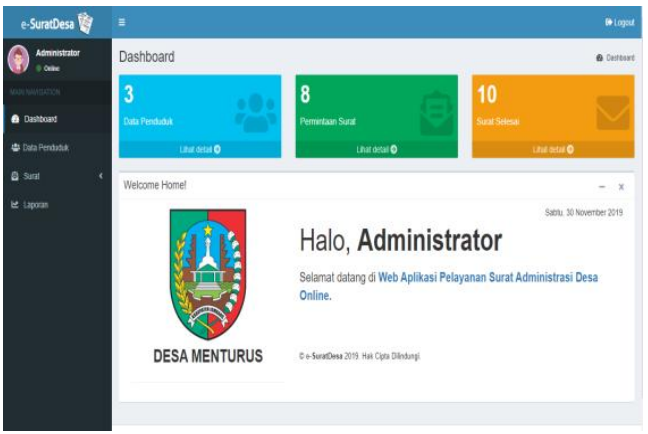

Gambar 6.Halaman Dashboard Aplikasi

\section{5) Tampilan Halaman Surat Selesai}

Halaman ini berisikan konfirmasi status surat selesai dibuat. Halaman terdiri dua konfirmasi yaitu status selesai dan cetak surat yang selesai. Berikut ini tampilannya seperti yang terlihat pada Gambar 7.

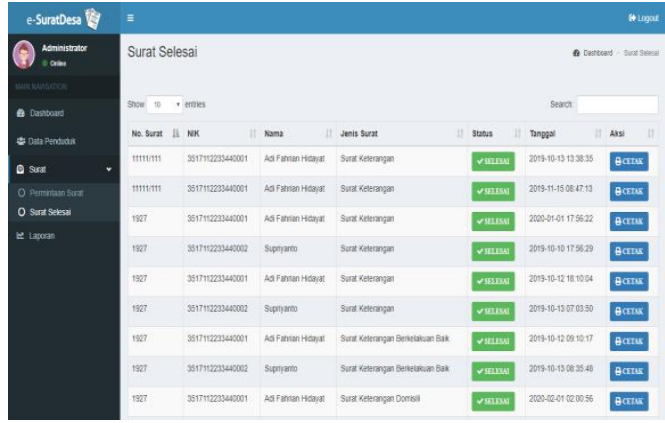

Gambar 7. Halaman Surat Selesai

\section{6) Tampilan Halaman Permintaan Surat}

Halaman ini berisi informasi surat ini terdapat beberapa keterangan proses dalam pengurusan surat apakah dalam proses pending atau sudah terkonfirmasi. Berikut ini tampilan halaman cara pemesanan yang terlihat pada Gambar 8 .

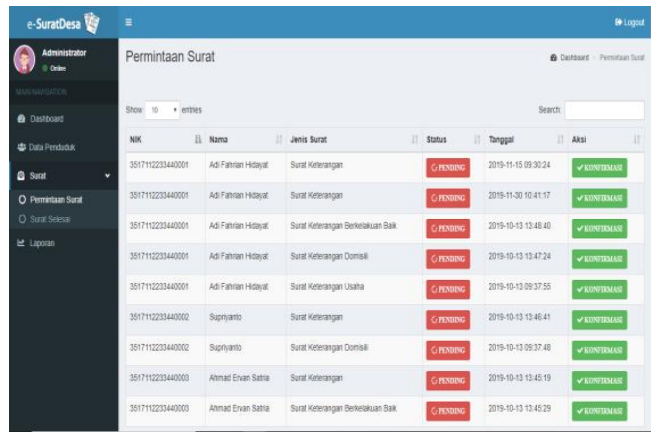

Gambar 8. Halaman Proses Permintaan Surat

\section{7) Tampilan Halaman}

Halaman ini digunakan mencetak laporan. Berikut ini adalah salah satu contoh pembuatan surat keterangan yang sudah tercetak. Tampilannya seperti yang terlihat pada Gambar 9.

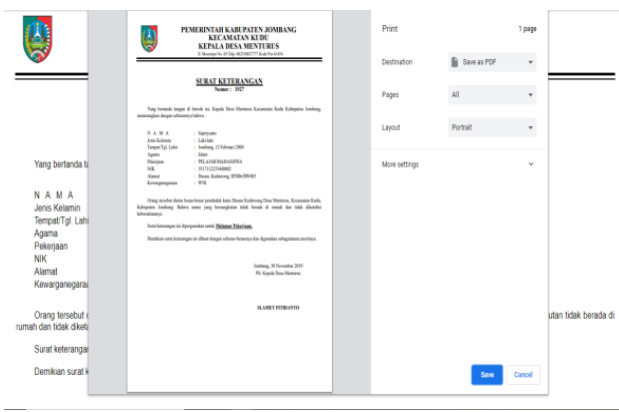

Gambar 9. Halaman Surat Keterangan

\section{HASIL}

Setelah dilaksanakan pelatihan pada tanggal 27 dan 28 Desember 2019, hasil yang diperoleh dari pelatihan tersebut adalah :

1) Sebanyak 5 peserta memahami dan sepakat akan pentingnya penggunaan teknologi informasi dalam membantu administrasi, terutama dalam mendukung kegiatan administrasi pelayanan surat secara online.

2) Peserta pelatihan dapat mengikuti dengan baik setiap praktikum misalnya instalasi software aplikasi E-SuratDesa.

3) Peserta pelatihan dapat mengikuti dengan baik praktikum entry data penduduk.

4) Peserta pelatihan dapat mengikuti dengan baik praktikum pelayanan pembuatan surat.

5) Peserta pelatihan dapat mengikuti dengan baik praktikum Praktikum pelayanan pembuatan surat dan pembuatan laporan.

6) Setiap peserta pelatihan dapat mempraktekkan setiap instruksi yang diberikan oleh pemateri yang berkaitan dengan cara penggunaan website $E$ SuratDesa.

Berikut ini dokumentasi foto hasil pelaksanaan pelatihan PKM yang telah 
dilaksanakan pada tanggal 27 dan 28 Desember 2019, dan dilaksanakan di Kantor Desa Menturus. Sedang peserta merupakan perangkat desa Menturus dengan jumlah peserta 5 orang.

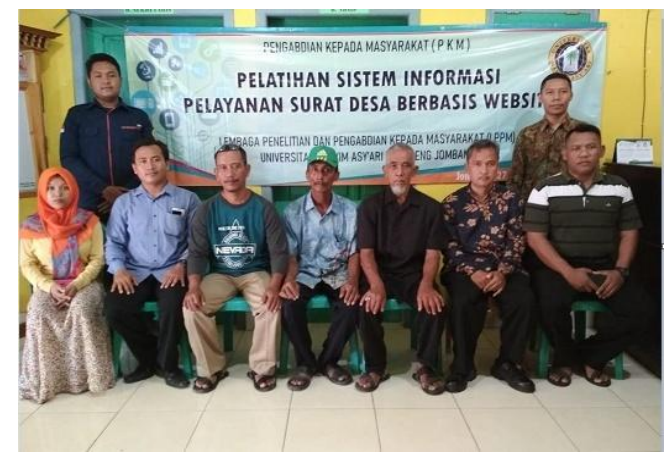

Gambar 10. Foto Pelaksanaan PKM 1

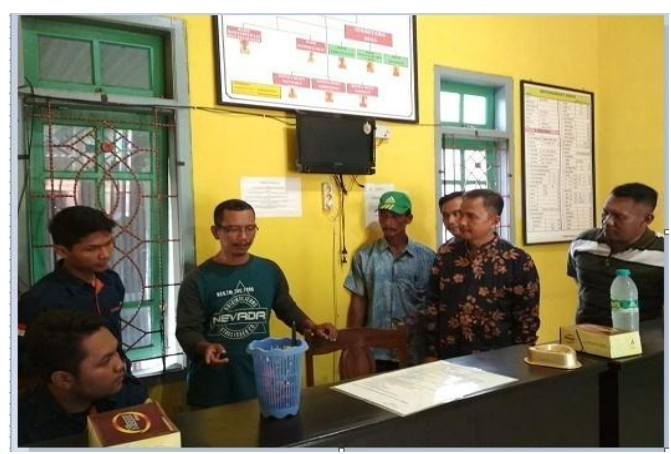

Gambar 11. Foto Pelaksanaan PKM 2

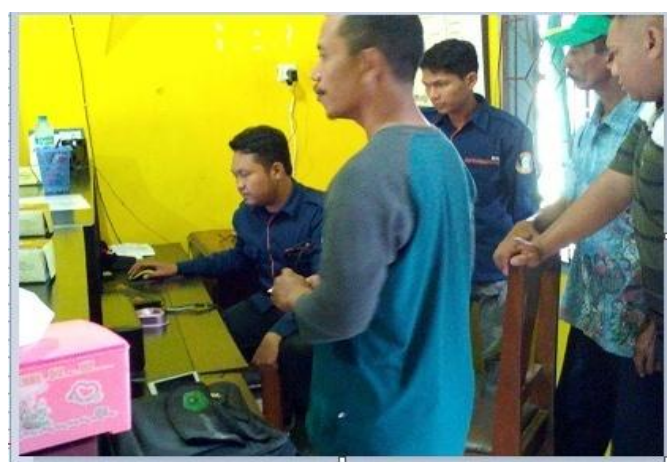

Gambar 12. Foto Pelaksanaan PKM 3

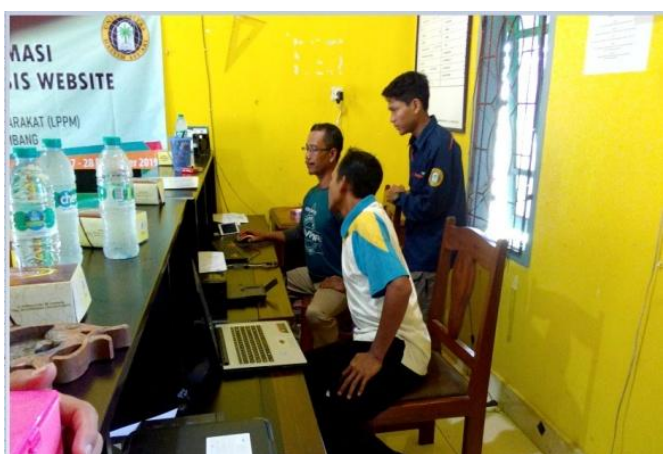

Gambar 13. Foto Pelaksanaan PKM 4

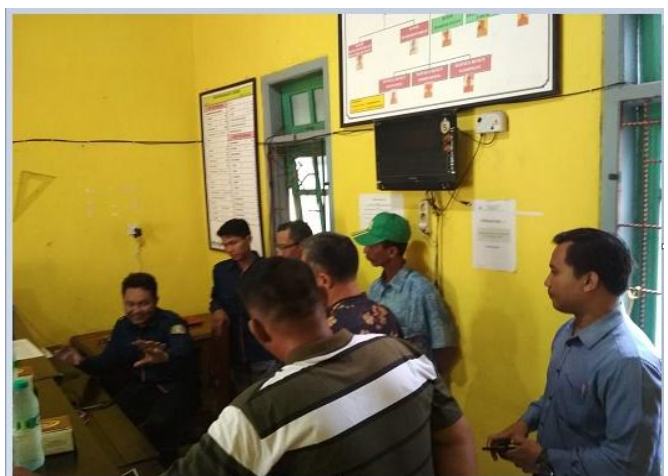

Gambar 14. Foto Pelaksanaan PKM 5

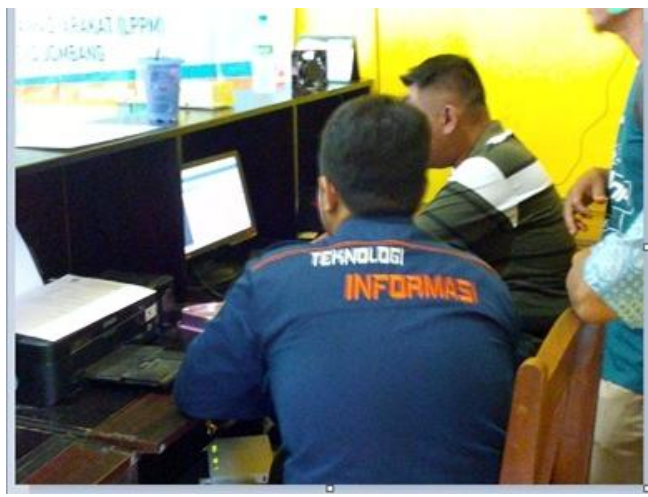

Gambar 15. Foto Pelaksanaan PKM 6

\section{ANALISA}

Berdasarkan hasil yang didapatkan pada saat pelatihan, diketahui bahwa semua peserta antusias dalam menyimak dan mempraktekkan setiap materi yang disampaikan, hal tersebut terbukti dengan adanya pertanyaan dari peserta. Selain itu para peserta juga sangat ramah dan menerima kedatangan tim PKM, sehingga tim dapat dengan mudah menyampaikan materi maupun praktikum aplkasi kepada peserta. Diharapkan dengan adanya pelatihan ini akan memberikan 
wawasan dan pengetahuan kepada para peserta tentang peranan teknologi informasi pada administrasi desa, terutama pembuatan surat desa.

\section{Evaluasi Kegiatan}

Kegiatan pelatihan ini dikatakan berhasil jika mayoritas peserta memahami setiap materi yang disampaikan oleh tim pelaksana PKM. Untuk itu pada akhir pelatihan peserta diminta mengisi kuesioner pemahaman peserta terhadap materi dan praktikum. Berikut ini hasil rekapitulasi kuesoiner peserta.

\section{1) Pemahaman Peserta Terhadap Materi}

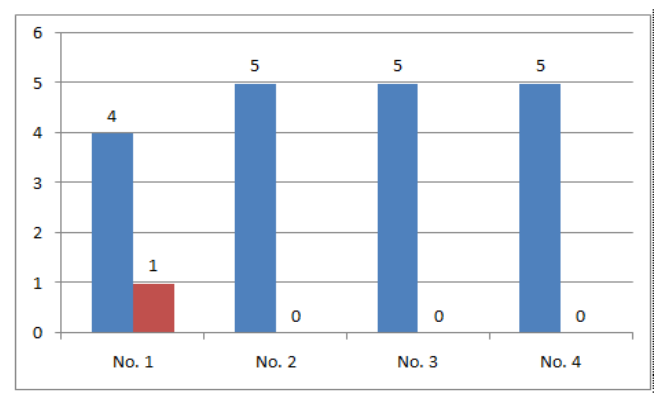

Gambar 16. Grafik Pemahaman Materi dan Praktikum

Berdasarkan data pada Gambar 16, dapat disimpulkan bahwa semua peserta dapat memahami dan mengerti terkait materi dan praktikum yang disampaikan dan dapat memberikan nilai manfaat bagi para peserta pelatihan, sehingga pemberian materi yang disampaikan pemateri dapat dikatakan berhasil.
2) Penggunaan dan Pemanfaatan Sistem ESuratDesa

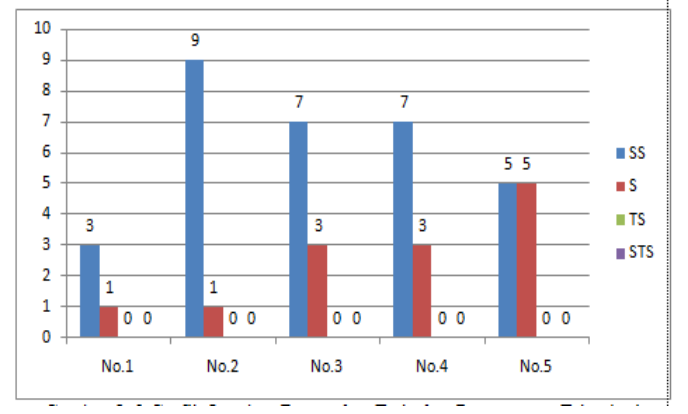

Gambar 17. Grafik Panggunaan dan Pemanfaatan Sistem E-SuratDesa dari Responden Masyarakat.

Berdasarkan data pada Gambar 17 diatas, dapat disimpulkan bahwa semua penduduk yang mengurus surat memperoleh manfaat dapat memahami dan menggunakan sistem $E$ SuratDesa dan setuju dengan adanya penggunaan teknologi informasi dalam membantu menyelesaikan masalah surat administrasi desa.

\section{SIMPULAN}

Implementasi dari sistem ini kepada perangkat desa Menturus telah dilaksanakan pada tanggal 27 dan 28 Desember 2019, dengan cara pelaksanaan pelatihan pemanfaatan teknologi dan praktikum langsung menggunakan website E-SuratDesa. Peserta yang hadir sebanyak 5 peserta yang terdiri dari perangkat desa Menturus.

Hasil pelaksanaan pelatihan dan praktikum dievaluasi dengan pengisian kuesioner oleh para peserta dan responden yang menunjukkan bahwa semua peserta dapat memahami semua materi yang disampaikan saat pelatihan dan semua peserta setuju dengan adanya penggunaan teknologi informasi dalam membantu proses administrasi desa, khususnya pengurusan surat-menyurat. 


\section{DAFTAR PUSTAKA}

Amrullah, F., \& David M., R. (2018).

Perancangan Sistem Informasi

Pengelolaan Administrasi Surat

Menyurat di Kantor Desa Sumberdem

Kecamatan Wonosari Kabupaten

Malang. Seminar Nasional Sistem

Informasi FTI UNMER Malang 2018, 10.

Kementrian Dalam Negeri, (2016) Peraturan Menteri Dalam Negeri No 47 tahun 2016. Kementrian Dalam Negeri. Diambil dari htpp://www.kemendagri.go.id/produkhukum/2016/08/23/adminstrasipemerintahan-desa.

Kurniati, R., Jaroji, \& Agustiawan. (2018). Sistem Layanan Mandiri Di Kantor Desa. Jurnal Inovtek Polbeng - Seri Informatika, 8.

Suryadi, I. 2013. Sistem Informasi Pengelolaan Surat Menyurat Pada kantor Kepala Desa Air Anyir. Pangkal Pinang.

Priyadi, D. A., \& Lestari, E. W. (2018). Perancangan Sistem Informasi Pelayanan Surat Menyurat Pada Kantor Desa Tanjungsari Kutowinangun Kebumen Berbasis Desktop. Jurnal Teknik Komputer AMIK BSI, 8.

PT. Bisma Teknologi Nusantara. (2019). Tentang Kami - PT. Bisma Teknologi Nusantara. Dipetik September 24, 2019, dari PT. Bisma Teknologi Nusantara: https://www.bismalabs.co.id/p/tentangkami 